\title{
Pore Interconnectivity Analysis of Porous Three Dimensional Scaffolds of Poly (3-Hydroxybutyric Acid) (PHB) and Poly(3-Hydroxybutyric-co-3-Hydroxyvaleric Acid) (PHBV) Through Non-Invasive Color Staining Method
}

(Analisis Kebolehjaringan Liang bagi Struktur Perancah Tiga Dimensi Poly(3-Hydroxybutyric Acid) (PHB) dan Poly(3-Hydroxybutyric-co-3-Hydroxyvaleric Acid) (PHBV) melalui Kaedah Pengotoran Warna tidak Invasi)

\author{
SAIFUl IrWAN Zubairi, ATHANASIOS MANTALARIS* \& ALEXANDER BISMARCK
}

\section{ABSTRACT}

Polyhydroxyalkanoates (PHAs) has been investigated for more than eighty years. Ever since then, the scientists are kept on synthesizing and developing new polymers and application to suit human interests nowadays. The resourcefulness of PHAs has made them a good candidates for the study of their potential in a variety of areas from biomedical/medical fields to food, packaging, textile and household material. In medical field (specifically in tissue engineering application), producing a biocompatible 3-D scaffold with adaptable physical properties are essential. However, to the best of our knowledge, scaffolds from $P H B$ and PHBV with thickness greater than $1 \mathrm{~mm}$ have not been produced yet. In this work, PHB and PHBV porous 3-D scaffolds with an improved thickness greater than $4 \mathrm{~mm}$ was fabricated using conventional method of solvent-casting particulate-leaching (SCPL). A preliminary assessment on the improved thickness 3-D scaffolds was carried out to examine its pore interconnectivity by using non-invasive color staining method. The vertical cross sections image of the stained scaffolds was analyzed by image analyzer software. This technique was considered simple, fast and cost effective method prior to the usage of super accurate analytical instruments (micro-computed tomography). The results showed that over $80 \%$ of the pores have been interconnected with the adjacent pores. Moreover, there was a good correlation between the predicted pore interconnectivity and porosity. These results indicated how well a simple technique can do by giving an overview of the internal morphology of a porous 3-D structure material.

Keywords: Color staining; PHBV; PHB; pore interconnectivity; 3-D scaffold

ABSTRAK

Polyhydroxyalkanoates (PHAs) telah dikaji lebih dari 80 tahun yang lalu. Semenjak dari itu, para saintis sentiasa mensintesis dan membangunkan polimer dan aplikasi baru bagi kemudahan dan penggunaan manusia sekarang. Kepelbagaian penggunaan PHAs telah menjadikan bahan tersebut sebagai calon yang sesuai dalam mengkaji pelbagai potensi daripada bidang bioperubatan/perubatan ke makanan, pembungkusan, tekstil dan bahan penggunaan di rumah. Dalam bidang perubatan (terutama sekali dalam aplikasi kejuruteraan tisu, penghasilan struktur perancah 3-D yang bioserasi dengan pengadaptasian ciri fizikal adalah penting. Tetapi, sehingga kini, masih tiada lagi struktur perancah daripada PHB dan PHBV dengan ketebalan melebihi $1 \mathrm{~mm}$ dapat dihasilkan.Dalam kajian ini, struktur perancah 3-D PHB dan PHBV dengan penambahbaikan ketebalan melebihi $4 \mathrm{~mm}$ telah dapat difabrikasi menggunakan kaedah konvensional pelarut-pembentuk larut serap partikulat (SCPL). Penilaian awalan terhadap struktur perancah 3-D telah dijalankan bagi menilai kebolehjaringan liang menggunakan kaedah pengotoran warna tidak invasi. Imej keratan rentas bagi struktur perancah yang dikotorkan dianalisis menggunakan perisian penganalisis imej. Kaedah ini dianggap mudah, pantas dan kos efektif sebelum penggunaan peralatan analitikal canggih (seperti tomografi mikro berkomputer). Keputusan kajian menunjukkan bahawa lebih $80 \%$ liang telah dibolehjaringkan dengan liang-liang yang berdekatan. Sebagai tambahan, terdapat kolerasi yang baik antara jangkaan kebolehjaringan liang dan keliangan. Keputusan ini memberi indikasi bahawa ia merupakan teknik yang mudah dalam memberikan gambaran awal tentang morfologi dalaman struktur bahan perancah 3-D.

Kata kunci: Kebolehjaringan liang; pengotoran warna; PHBV; PHB; Struktur 3-D

\section{INTRODUCTION}

Poly(hydroxyalkonate)s (PHA) are degradable, biocompatible and thermoplastic aliphatic polyesters produced by various microorganisms (Chung et al 2003). The most common type is the polyhydroxybutyrate (PHB) which is coming from the polymerization of 3-hydroxybutyrate monomer. It has a physicochemical feature in addition to mechanical properties similar to those of polypropylene (PP) and polylactic-co-glycolic acids (PLGA) (Lianlai et al. 1997; Williams et al. 1999). Meanwhile, its copolymers 
with diverse ratios of hydroxyvalerate (HV) which are known as polyhydroxybutyrate-valerate (PHBV) are also extensively used. These copolymers are less crystalline, more flexible and more readily processable than PHB itself (Gassner \& Owen 1996; Tabesh et al. 2009). In addition, these copolymers polyhydroxybutyrate-valerate (PHBV) are frequently used as packaging material due to its reasonably less stiffer, less brittle and more tougher than the PHB (Siracusa et al.2008). In that case, their various properties such as natural origin, biodegradability, biocompatibility and non-toxicity make them suitable for a variety of applications in medicine and industry (Pouton \& Akhtar 1996; Qu et al. 2006). One of the vital and demanding applications recently is for the use as scaffolding materials for tissue engineering and regenerative medicine (TERM) (Cheng et al. 2006). The principal function of a scaffold is to maneuver cell behavior such as migration, proliferation, differentiation, maintenance of phenotype and apoptosis by facilitating sensing and responding to the environment via cell-matrix and cell-cell communications (Tabesh et al. 2009). To summarize, this study aimed at using the non-invasive color staining method on porous three dimensional scaffolds of poly(3-hydroxybutyric acid) (PHB) and poly(3-hydroxybutyric-co-3-hydroxyvaleric acid) (PHBV) for the analysis of pore interconnectivity. The pore interconnectivity is essential to allow for tissue regeneration, vascularization and cell in-growth. In addition, pore interconnections act as pathways for cells transport to the pore space that eventually provides a location for tissue growth and formation. For that reason, this color staining procedures would allow scientist to opt to a simple, fast and non-invasive method in analyzing the pathways between pores. The results would perhaps to provide an overview on its internal structure morphology prior to the analysis of scanning electron microscopy (SEM) and micro-computed tomography $(\mu-\mathrm{CT})$.

\section{MATERIALS AND METHODS}

\section{MATERIALS}

Poly(3-hydroxybutyric acid) (PHB; $M_{\mathrm{w}}=300,000 \mathrm{~g} \mathrm{~mol}^{-1}$; CAS No. 29435-48-1), poly(3-hydroxybutyric acid-co3-hydroxyvaleric acid) (PHBV; $M_{\mathrm{w}}=680,000 \mathrm{~g} \mathrm{~mol}^{-1}$ with $12 \%(\mathrm{w} / \mathrm{w})$ polyhydroxyvalerate (PHV) content; CAS No. 80181-31-3) and Alirazin Red S (Sigma-Aldrich ${ }^{\mathrm{TM}}$ ) were purchased from Sigma-Aldrich ${ }^{\circledR}$ (Dorset, United Kingdom). Chloroform $99.9 \%$ in purity (AnalaR ${ }^{\circledR}$ ) was obtained from VwR International (Leicestershire, United Kingdom).

\section{PREPARATION OF THE POROUS 3-D SCAFFOLDS}

Polymer concentrations of $4 \%(w / v)$ for PHB and PHBV (containing $12 \%$ by weight of polyhydroxyvalerate (PHV)) were prepared in $60 \mathrm{~mL}$ of boiled reflux chloroform (99.9\% purity) at $60^{\circ} \mathrm{C}$ for $8.2 \pm 1.48 \mathrm{~min}$ and $17.8 \pm 2.28$ min, respectively, in a fume cupboard. Polymer solutions were cooled down for 10 min prior to mixing with sodium chloride. Once cooled, the polymer solutions were added evenly over an aluminum foil-coated glass Petri-dish (internal diameter $8.8 \times$ height $1.8 \mathrm{~cm}$ ). Sodium chloride crystals with an approximate particle size of 212 to 850 $\mu \mathrm{m}$ were then poured evenly and mixed into the polymer solutions with continuous stirring until the polymer-solvent solution became pasty, thick and packed. The fully filled pasty Petri-dish was tapped a few times so that the content became compact and even. This procedure was carried out in the fume cupboard. Subsequently, the packed-in pasty were put immediately inside a lyophilization flask (to avoid the etching effect) and air-dried for 2 days for complete solvent evaporation. The dried-casting polymers were peeled carefully from the aluminum foil and then dialyzed with $10 \mathrm{~L}$ of cold deionized water (DIW) at $21^{\circ} \mathrm{C}$ for each polymer for 2 days to remove all sodium chloride crystals ( 2 dried casts/10 L DIW). The deionized water was changed twice a day. Wet porous materials were placed onto tissue paper 3 to 4 times until they became partially dry. They were frozen at $-70^{\circ} \mathrm{C}$ for $3 \mathrm{~h}$ and then transferred into a cryostat bath containing ethylene glycol $\left(-15^{\circ} \mathrm{C}\right)$ to lyophilize the remaining deionized water and chloroform via the sublimation process under vacuum pressure of 2 mbar for 2 days. Scaffolds were then cut into cuboids with an approximate size of $10 \times 10 \times 5 \mathrm{~mm}$ prior to the noninvasive color staining.

\section{PREPARATION OF STAINING SOLUTION}

Alirazin Red S (Sigma-Aldrich ${ }^{\mathrm{TM}}$ ) was dissolved in deionized water (DIW) with the concentration of $0.4 \%$ $(\mathrm{w} / \mathrm{v})$. The solution was stored in a dark place prior to the staining process.

\section{NON-INVASIVE COLOR STAINING}

Interconnectivity is an important feature for porous materials, especially for tissue-engineering scaffolds. It is difficult to obtain a complete 3-D information about interconnectivity through 2 -D images. Therefore, a simple experiment via color staining was performed to observe the pores interconnectivity (Shi et al. 2002). The polymeric porous 3-D scaffolds were soaked in the color staining solution of Alirazin Red S $(0.4 \%, \mathrm{w} / \mathrm{v})$ by means of normal soaking (without pressure) and forced entry (under vacuum pressure of 2 mbar) for 60 to $105 \mathrm{~min}$ and 5 min, respectively. After the soaking, the sample was dried, sectioned and pictured prior to the image analysis by mean of inverted color mapping exposure. Pores with red color apparently had been accessible, either directly or via neighboring pores.

\section{PORE INTERCONNECTIVITY ANALYSIS}

The magnified images of the vertical cross-section 3-D scaffolds were taken using instrument for optical microscopic imaging Dino-Lite AM-311s USB Microscope $10 \times-200 \times$ coupled with 5 high intensity LED (Figure 1). 
Image Analyzer 1.33 MeeSoft ${ }^{\mathrm{TM}}$ was used to quantify pore interconnectivity (\%) by using inverted color mapping exposure method (grayscale) from the generated histogram. The image histogram ( $y$-axis number of pixels vs. number of tones ( 0 to 255$)$ produced a distribution of tones which can be distinguished by the software. The formula for calculating pore interconnectivity (\%) is shown in Equation 1.

$\%$ Interconnectivity $=\Sigma$ Areas under the curve (grayscale area) $/\left[\sum\right.$ Areas under the curve (grayscale area) + Areas under the curve (unshaded area) $\times$ $100 \%$.

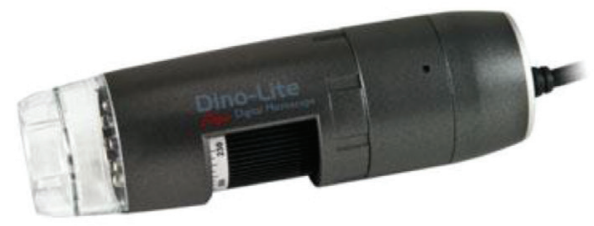

FIGURE 1. Instrument for optical microscopic imaging (Dino-Lite AM-311s USB Microscope 10x - 200x coupled with 5 high intensity LED)

\section{STATISTICAL ANALYSIS}

Data were presented as means \pm standard deviation (sd) of mean. Statistical comparisons were performed using Students t-test (PASW version 17.0 IBM Co.). A $p<0.05$ was considered significant.

\section{RESULT AND DISCUSSION}

\section{QUALITATIVE ANALYSIS: VISUAL ASSESSMENT}

Interconnections act only as pathways for nutritional elements, vascularization and cells distribution across the 3-D porous scaffold (Lu et al. 1999). For that reason, the color staining method would possibly considered as simple, fast and non-invasive method to analyze interconnectivity between pores in PHB and PHBV porous 3-D scaffolds. Table 1 and Figure 2 show visible observation of vertical cross sections of both polymeric porous 3-D scaffolds. In normal soaking method, PHB produced a mild peripheral color staining region with one big unstained spot (Figure 2(a)) whilst PHBV produced only scattered unstained spots (Figure 2(b)). This phenomenon could possibly be due to the polymers wettibility. The wettibility of both 3-D scaffolds has been studied beforehand (Figure 3 ). The result showed that PHB became totally submerged with a faster absorbability rate than PHBV (within $60 \pm 3$ min) owing to the less hydrophobic character than PHBV (105 $\pm 5 \mathrm{~min})$. However, in forced entry method under vacuum, homogenously staining region was presented on both polymeric 3-D scaffolds (Figure 2(a) and 2(b)). No unstained region occurred throughout this process. The given vacuum pressure ( 2 mbar) might have made the porous structure of the 3 -D scaffolds to be easily penetrated by the staining solution. Furthermore, all treated scaffolds vertical sections show a distinguishable staining region as compared with control (a tonal distribution of control was less than $2 \%$ : 5.1/255) $(p<0.05)$.

\section{QUANTITATIVE ANALYSIS: IMAGE ANALYZER}

Figure 4 shows a screen captured of one image histogram in grayscale generated from the image analyzer software. In definition, an image histogram is a type of histogram that acts as a graphical representation of the tonal distribution in a digital image (Freeman 2005). It plots the number of pixels ( $y$-axis) for each tonal value ( $x$-axis: $0-255)$. Figure 5 depicts a microscopic images ( $10 \times$ and $20 \times$ magnification) demonstrating a vertical cross section of polymeric porous 3-D scaffolds stained by Alirazin Red S (Sigma-Aldrich ${ }^{\mathrm{TM}}$ ). From the analyzed image histograms, predicted pore interconnectivity (\%) was generated based on the inverted color mapping exposure (grayscale image). For normal soaking method, PHBV has a higher pore interconnectivity as compared to PHB $(p<0.05)$. The results were in good agreement with those obtained from porosity analysis (data not shown) wherein PHBV $(92.17 \pm 0.73)$ produced higher porosity than PHB $(82.12 \pm 0.18)(p<0.05)$. Hence, greater capillary porosity in the porous 3 -D scaffolds leads to faster water uptake (Hazaree et al. 2011). Meanwhile, in forced entry method, both polymers generated the same interconnectivity (\%). Pore ruptured may in fact be the main reason of high value observed. For that reason, the staining solution might have penetrated deep into the ruptured closed pores with the aid of pressure. Overall, over $80 \%$ of the pores have been interconnected with the adjacent pores. The results indicated that this

TABLE 1. Visible observation of the 3-D scaffold vertical cross sections

\begin{tabular}{|c|c|c|}
\hline \multirow{2}{*}{ Methods } & \multicolumn{2}{|c|}{ 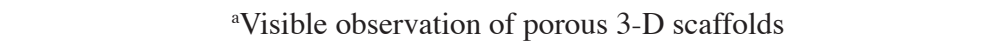 } \\
\hline & PHB $(4 \%, w / v)$ & $\operatorname{PHBV}(4 \%, \mathrm{w} / \mathrm{v})$ \\
\hline Normal soaking & $\begin{array}{l}\text { Mild peripheral color staining with one } \\
\text { big unstained spot }\end{array}$ & $\begin{array}{l}\text { Mild color staining with scattered } \\
\text { unstained spots }\end{array}$ \\
\hline Forced entry ( 2 mbar) & Color staining almost homogeneously & Color staining almost homogeneously \\
\hline
\end{tabular}

${ }^{a}$ Visible observation on the vertical cross-section of the porous 3-D scaffolds 

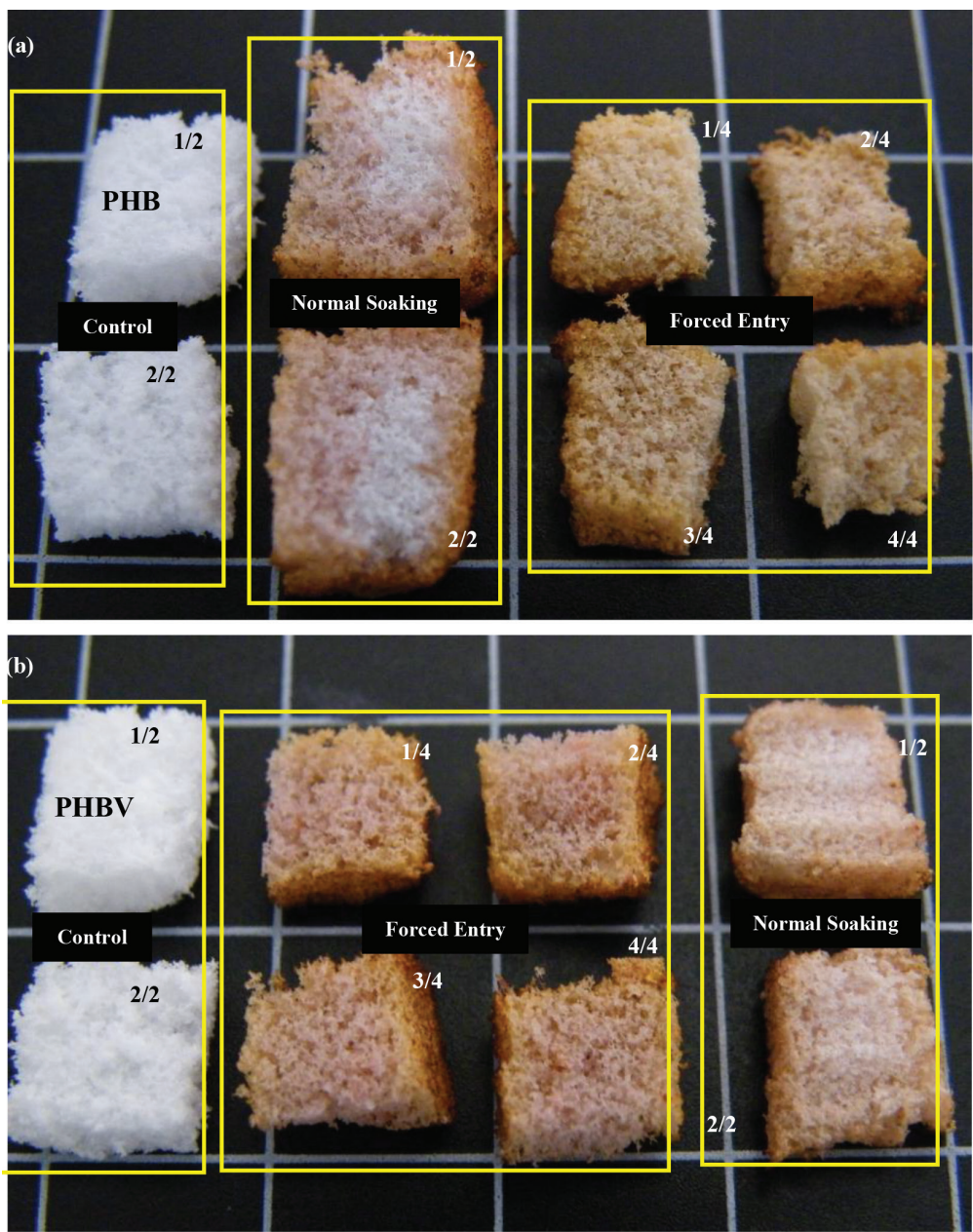

FIGURE 2. Photographs demonstrating the vertical cross section of polymeric porous 3-D scaffolds stained by using the Alirazin Red S (Sigma-Aldrich ${ }^{\mathrm{TM}}$ ). Two different methods were conducted which are by means of the normal soaking (without pressure) and forced entry (under vacuum pressure of 2 mbar for 5 min)

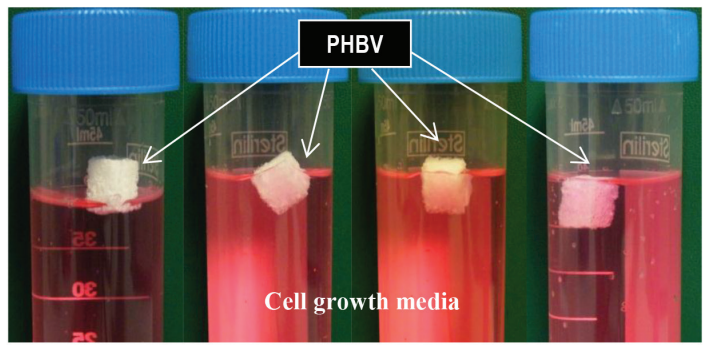
$1 \mathrm{~min}$
30 mins
$60 \mathrm{mins}$
$105 \operatorname{mins}$

(a) Submerging but not sinking

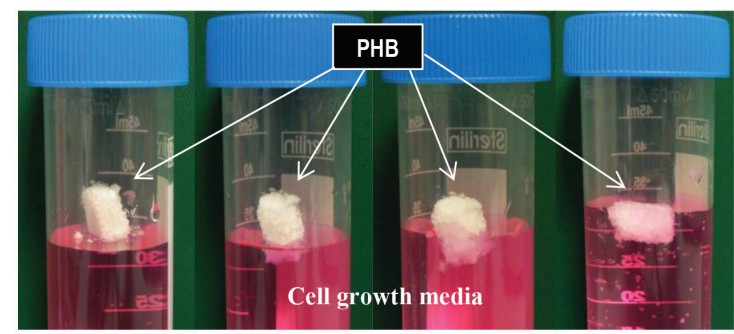

1 min

30 mins

45 mins

$60 \mathrm{mins}$

(b) Submerging but not sinking

FIGURE 3. Photographs demonstrated the submerging of (a) PHBV (4\%,w/v) porous 3-D scaffold and (b) PHB $(4 \%, w / v)$ porous 3-D scaffold into cell culture growth media (IMDM) as a function of time 


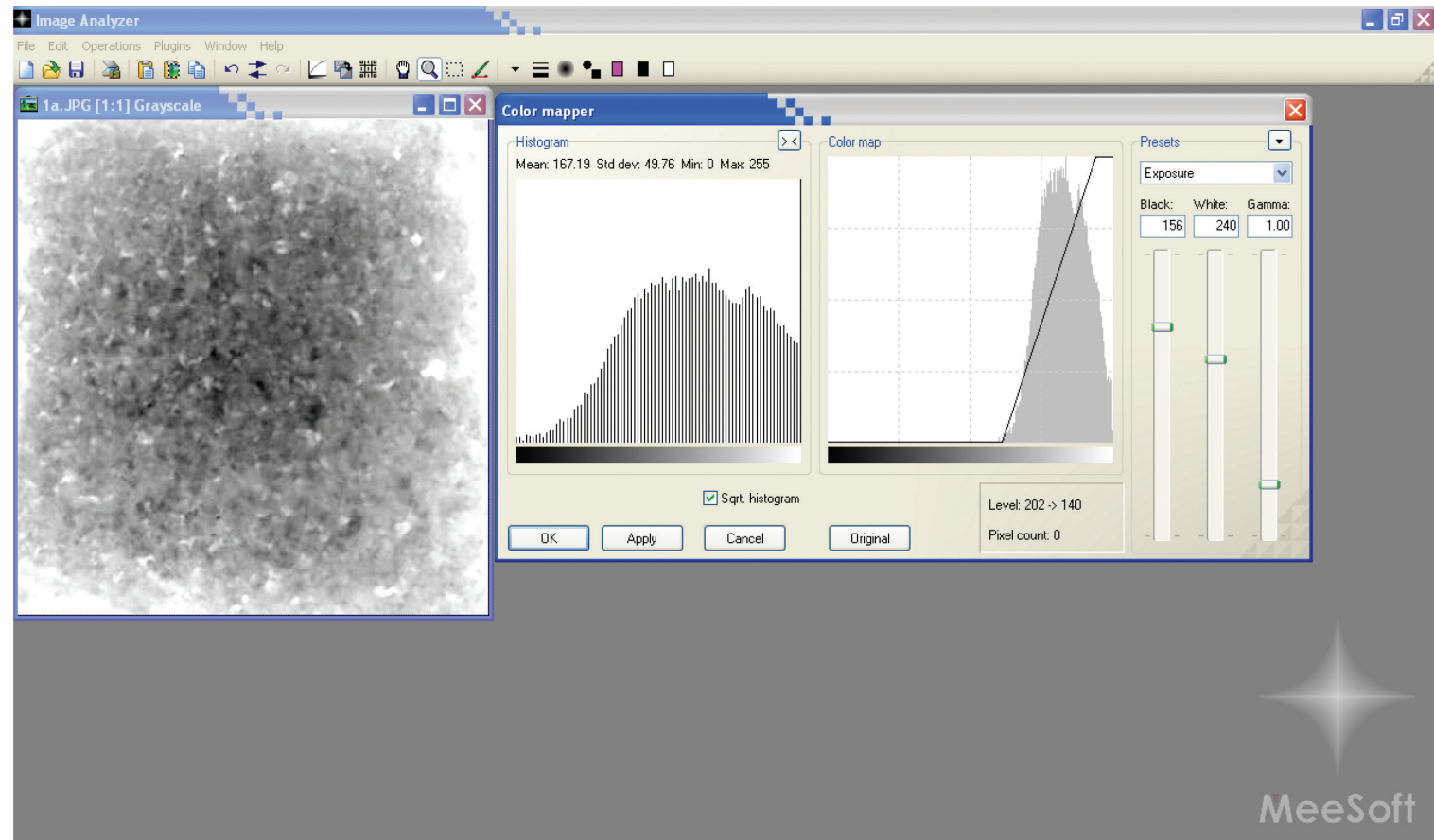

FIGURE 4. Screen captured of an image histogram in grayscale generated from the image analyzer software

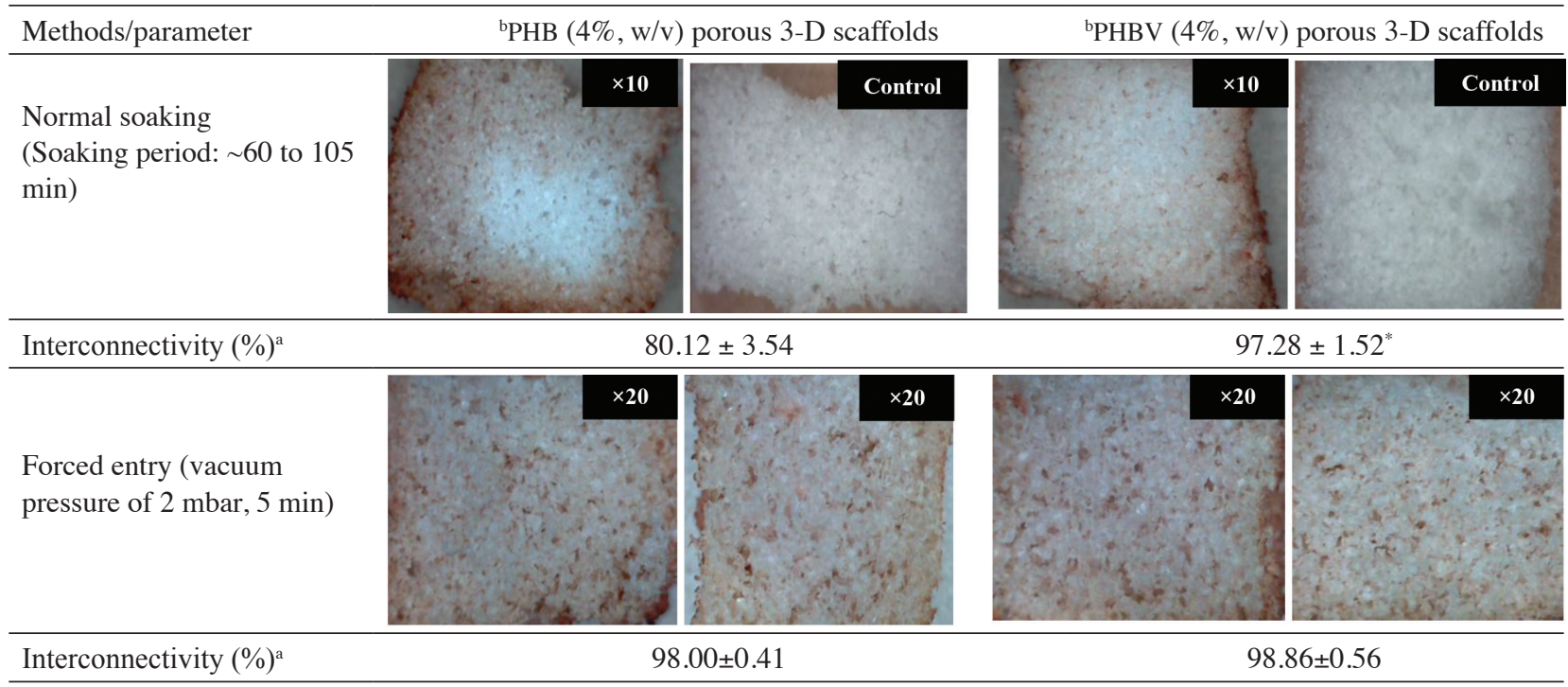

${ }^{\mathrm{a}}$ Interconnectivities were analyzed by using Image Analyzer 1.33 MeeSoft $^{\mathrm{TM}}$ (inverted color mapping exposure)

boptical microscopic images were taken by using Dino-Lite AM-311s USB Microscope 10x - 200x

${ }^{*} p<0.05$ as compared with PHB $(n=4)$

FIGURE 5. Microscopic images (10× and 20x magnification) demonstrating the vertical cross section of polymeric porous 3-D scaffolds stained by Alirazin Red S (Sigma-Aldrich ${ }^{\mathrm{TM}}$ ). \% Interconnectivity was calculated based on the inverted color mapping exposure histogram

fabricated 3-D scaffolds have great potential to be used as a biomimetic scaffold to study any tissues (especially cancerous tissues) ex vivo.

\section{CONCLUSION}

Besides porosity and pore size, pore interconnectivity is considered as one of the important morphological properties of a biomaterial scaffold for tissue engineering application. The values of predicted pore interconnectivity (\%) were proposed for the initial assessment of PHB and PHBV porous $3-D$ scaffolds as to mimic any tissues that has a thickness greater than $5 \mathrm{~mm}$. A good correlation between these predicted pore interconnectivity and porosity (data not shown) was observed. This preliminary result may well be used as an overview of its internal morphology. 
Hence, further manipulation during the fabrication process is highly recommended to produce high permeability prior to the cell culture work.

\section{ACKNOWLEDGEMENTS}

The authors would like to thank the Ministry of Education (MOE), Malaysia and Richard Thomas Leukemia Fund, United Kingdom for providing the financial support to this project.

\section{REFERENCES}

Cheng, S., Chen, G.Q., Leski, M., Zou, B., Wang, Y. \& Wu, Q. 2006. The effect of d,1- $\beta$-hydroxybutyric acid on cell death and proliferation in L929 cells. Biomaterials 27(20): 3758-3765.

Chung, C.W., Kim, H.W., Kim, Y.B. \& Rhee, Y.H. 2003. Poly(ethylene glycol)-grafted poly(3-hydroxyundecenoate) networks for enhanced blood compatibility. International Journal of Biological Macromolecules 32(1-2): 17-22.

Freeman, M. 2005. The Digital SLR Handbook. Lewes: ILEX.

Gassner, F. \& Owen, A.J. 1996. Some properties of poly(3hydroxybutyrate)-poly(3-hydroxyvalerate) blends. Polymer International 39(3): 215-219.

Hazaree, C., Wang, K., Ceylan, H. \& Gopalakrishnan, K. 2011. Capillary transport in RCC: water-to-cement ratio, strength, and freeze-thaw resistance. J. Mater. Civ. Eng. 23(8): 11811191.

Lu, J.X., Flautre, B., Anselme, K., Hardouin, P., Gallur, A., Descamps, M. \& Thierry, B. 1999. Role of interconnections in porous bioceramics on bone recolonization in vitro and in vivo. Journal of Materials Science: Materials in Medicine 10(2): 111-120.

Lianlai, Z., Xianmo, D., Shujie, Z. \& Zhitang, H. 1997. Biodegradable polymer blends of poly(3-hydroxybutyrate) and poly(-D,L-lactide)-co-poly(ethylene glycol). Journal of Applied Polymer Science 65(10): 1849-1856.

Pouton, C.W. \& Akhtar, S. 1996. Biosynthetic polyhydroxyalkanoates and their potential in drug delivery. Advanced Drug Delivery Reviews 18(2): 133-162.
Qu,X.H., Wu, Q., Liang, J.,Zou, B. \& Chen, G.Q. 2006. Effect of 3-hydroxyhexanoate content in poly(3-hydroxybutyrate-co3-hydroxyhexanoate) on in vitro growth and differentiation of smooth muscle cells. Biomaterials 27(15): 2944-2950.

Shi, H.L., Joost, R.D., Wijn, P.L. \& Klaas, D.G. 2002. Synthesis of macroporous hydroxyapatite scaffolds for bone tissue engineering. Journal of Biomedical Materials Research 61(1): 109-120.

Siracusa, V., Rocculi, P., Romani, S. \& Rosa, M.D. 2008. Biodegradable polymers for food packaging: A review. Trends in Food Science \& Technology 19(12): 634-643.

Tabesh, H., Amoabediny, G., Nik, N.S., Heydari, M., Yosefifard, M., Siadat, S.O.R. \& Mottaghy, K. 2009. The role of biodegradable engineered scaffolds seeded with Schwann cells for spinal cord regeneration. Neurochemistry International 54(2): 73-83.

Williams, S.F., Martin, D.P., Horowitz, D.M. \& Peoples, O.P. 1999. PHA applications: addressing the price performance issue: I. Tissue engineering. International Journal of Biological Macromolecules 25(1-3): 111-121.

Saiful Irwan Zubairi

School of Chemical Sciences \& Food Technology

Faculty of Science \& Technology

Universiti Kebangsaan Malaysia

43600 Bangi, Selangor Darul Ehsan

Malaysia

Athanasios Mantalaris* \& Alexander Bismarck

Department of Chemical Engineering, Imperial College London South Kensington Campus, London SW7 2AZ

United Kingdom

*Corresponding author; email: a.mantalaris@imperial.ac.uk

Received: 14 November 2013

Accepted: 3 June 2015 